University for Business and Technology in Kosovo

UBT Knowledge Center

Oct 29th, 5:00 PM - 5:15 PM

\title{
Conditions for an Effective Democracy in Multicultural Societies and Countries
}

Flora Kadriu

University for Business and Technology, kadriu.flora@gmail.com

Follow this and additional works at: https://knowledgecenter.ubt-uni.net/conference

Part of the International Relations Commons

\section{Recommended Citation}

Kadriu, Flora, "Conditions for an Effective Democracy in Multicultural Societies and Countries" (2017). UBT International Conference. 318.

https://knowledgecenter.ubt-uni.net/conference/2017/all-events/318

This Event is brought to you for free and open access by the Publication and Journals at UBT Knowledge Center. It has been accepted for inclusion in UBT International Conference by an authorized administrator of UBT Knowledge Center. For more information, please contact knowledge.center@ubt-uni.net. 


\title{
Conditions for an Effective Democracy in Multicultural Societies and Countries
}

\author{
Flora Kadriu \\ UBT - Higher Education Institution, Lagjja KALABRIA p.n., 10000 Prishtina, Kosovo \\ flora.kadriu@ubt-uni.net
}

\begin{abstract}
The motive behind this paper is exploration of the conditions for effective democracy in multicultural societies and countries. The two principles of social setting in the context of classical parliamentary democracy ensue from a special set of civil and political rights, as basis for cultural identity, which further underlies the collective cultural rights (CCRs) or group-differentiated rights (GDRs). Such setting is initiation into a serious process of changes in classical democracy. The cultural diversity accommodation in the political system of a given democracy is an intricate process that shifts the liberal justice concept and requires a new political system dubbed by some authors as multicultural democracy, instead of merely democracy in multicultural societies. This theory is chiefly known as "consociational theory of democracy". In this paper, efforts are made to establish the new theoretic and experiential institutions and relations we are to call conditions for an effective multicultural democracy.
\end{abstract}

Keywords: conditions for effective democracy, collective cultural rights, multicultural democracy

\section{Introduction}

Multiculturalism is no novelty; it has existed for quite some time. And neither is its spectacular radiance new to the history of politics. The problem of controlling multiculturalism was historically met by empires, "old" democracies, colonies, immigrant societies and-following the experimentation with communism-likewise by Eastern European countries. In modern times (at the beginning of the $20^{\text {th }}$ century), when the affirmation of the popular sovereignty principle withered the legitimacy of the great empires, Balkan and Central European countries faced their initial challenges in political institutionalisation of ethnocultural and religious minorities. The multicultural and multiconfessional space of the former empires presented both a challenge and a temptation to the newly formed countries regarding the treatment of peoples, ethnic and religious minorities, but also regarding the protection of their interests.

The "brilliant" return of multiculturalism represents a specific postmodern political phenomenon owing to the need for cultural and primary identity implications in light of the expansion of the massive, depersonalised structures of globalisation. [1] Authors like Will Kymlicka, Charles Taylor and others have made a major contribution to the moulding of the "multiculturalism" phenomenon in the nineties, giving it a central place in the restoration of liberal tradition.

Most countries in the world are culturally heterogeneous. This diversity raises a series of important and potentially differential issues. The state of continuous political conflict, that is, confrontation between minorities and majorities, is inevitable.Issues of strategic interactions to arise most 
frequently are: continuity and identity of minorities; regard for human rights; power sharing in the constitution and execution of governance and in political decision-making (on representative or administrative levels); position of these groups in the control and share of social wealth and "national" income; participation in business retransformation (in transitional economic reforms); efforts for resources in education (the use of languages in public or official communication); immigration policy; national symbols; choice of national anthem; public holidays; etc. Debating these issues reveals numerous weaknesses, or "sore points", even in the world's strongest democracies. This signals the necessity to peacefully resolve the indicated problems in a manner alluring to all modern countries, and especially to those with different modalities of cultural diversity. Having regard to the countries with identical or similar experiences, and to the authors addressing them, as a synthesis I shall derive a series of conditions fora relatively successful or effective consociational democracy.

\section{Institutional Conditions for a Relatively Successful or Effective Consociational Democracy}

The two principles of social setting in the context of classical parliamentary democracy ensue, in particular, from a special set of civil and political rights, as basis for cultural identity, which further underlies the collective cultural rights (CCRs) or group-differentiated rights (GDRs). Such setting is initiation into a serious process of changes in classical democracy some authors term concepts of consociational democracy, mosaic societies, pluralistic societies, disjunctive societies, segmented societies, divided societies, etc. On the one hand, that kind of cultural diversity accommodation in the political system of a given democracy is an intricate process that shifts the liberal justice concept, and, on the other, it allows sucha concept to produce an array of institutes and institutions in short, a new political system dubbed by some authors as multicultural democracy, and not merely democracy in multicultural societies. This theory is chiefly known as "consociational theory of democracy". [2]

But, which, in practice, are the new theoretic and experiential institutions and relations we are to call conditions for an effective multicultural democracy?

\section{Normative Solutions or Theses for Minimalistic Constitutional Engineering of a Multicultural Society}

Since multicultural societies contain plurality of cultural norms and practices, they regularly fail to reach a single cultural narrative serving as constitutional basis. [2] Hence, the constitution is such countries ought to carry two features: 1) to be generalenough (concept of a short constitution); and 2) to be capable of absorbing different solutions ensuing from dynamic negotiations among different groups at different levels of society. In principle, these solutions prove to be far more dynamic than solutions reached in homogeneous societies. As a primary requisite, the minimalistic constitutional engineeringshould therefore embed the core of relations in the area of intercultural accommodation (adaptation, adjustment), mainly referring to: the use of languages on central and local level; participation of group representatives in bodies and councils on central and local level; participation of group representatives in public administration; participation of group representatives in the Constitutional Court, and judiciary, in general; the use of ethnic symbols; solutions establishing state-budgeted cultural institutions and media. 
The general idea, direction and principle to be provided by the constitution isinclusiveness. This pertains both to the basic solutions stipulated in it and to the potentially new practices taking place in the future which the constitution cannot stipulate.

"Turn on - don't turn off" is the basic parameter of these societies, whereas it is crucial that there exists political culture, and not merely normative solutions through which this process is observed and embodied. [3]

Among the first solutions which constitutions of such consociational democracies should include is a modality for the veto concept. In essence, it should be set up in a defensive capacity (one instance of the defensive capacityof the veto concept modality is the positive experience with the Badinter voting in the Republic of Macedonia), which implies that the veto principle should ensure protection from the imposition of the majority will through outvoting, mainly in regard to issues concerning the cultural identity of minority groups. There still remain open questions: What does all that imply?Does it concern laws strictly referring to cultural rights and institutions-either in a narrow or a wider sense-and voting on mechanisms that provide resources for these rights (the budget)?

There are modalities for separate voting on the budget: allowing the right toveto parts of the state budget that provide resources for cultural rights, that is, resources for culture and education, whereas parts not directly related to culture rights be adopted through regular majority vote as stipulated in the constitution.

The constitution should also lay down high official positions, whereas, on the principle of equitable representation, representatives of minority cultures would hold offices. Of special importance are positions in the Constitutional Court and other courts, high political offices, and managing positions of the so called "public services".

The constitution can also provide for the concept of local government (local democracy) underlining direct attainment of minorities' influence on social life (this concept is thoroughly stipulated by law).

The constitution can also prescribe the fundamentals of electoral legislation, regarding two aspects, namely: 1) consociational democracies should necessarily ensure the principle of proportional representation, whereby cultural minorities will be given the opportunity to become politically visible; and 2) it is also important to prevent cultural imposition on the smallest of cultural minorities through the distribution of constituencies (electoral geometry). In consociational democracies it is often recommended that a single constituency is created on the territory of the entire country. [3]

Furthermore, this consociation concept is no strange to ensuring guaranteed seats for cultural minorities whocan in no way through the electoral system become politically visible.

\section{Legal Level of Inclusion}

The second level of the normative aspect, the legislative level, in consociational (multicultural) democracies, reveals at least two types of laws adopted by qualified majority. One type is laws where minority cultures have the right to a veto (such as the double-majority vote). Their number and scope is usually defined through special negotiations. Constitutions are incapable of providing exhaustive lists of such laws. The list of laws voted under the veto principle must encompass key laws on cultural reproduction of minorities. In this process of internal negotiations, there is a benefit from expert consultations (opinions, suggestions, directions, recommendations) with influential international organisations and countries - so that the process remains open to the application of 
international standards for the given area and, at the same time, be unburdened from political tension.

The second important legal solution refers to the regulation of relations in local democracy (local government, which is generally provided for in the constitution). These laws should, in principle, give minorities' ethnic (cultural) rights a territorial context - associating ethnic rights to a territory on a local level. Local government laws in these societies must ensure unhindered enforcement regarding: use of the languages of minority cultures; cultural symbols; local government; and, just as important, serious fiscal support to such practices. The local government in these societies should therefore exhibit serious capacity of vigour and effectiveness, or else the entire system will be pulled into crisis.

The electoral law, vis-à-vis the constitution, should address the issueof proportional representation and allow maximum fairness in the representation of minority cultural groups, in following the basic "one person, one vote" principle. In addition, the electoral law can provide for guaranteed seats in the Parliament for the smallest cultural groups, and also ensure electoral geometry that will yield equitable representation (regular suggestion is made that country's entire territory become a single constituency, thus providing equitable representation for the smallest cultural groups).

Laws in such areasas public administration and judiciary must also be drafted in line with the principle of inclusiveness or equitable representation of (at least) the relevant minority cultures. Namely, the public administration should function on the basis of professionalism and neutrality, as previously established by Max Weber. This principle in multicultural societies should be regarded yet more importantly, since the functioning of the administration is perhaps the sole connective on a national level. Encroaching on this principle may spur overall segregation along an ethnic line. Hence, it is imperative that the professionalism of the administration is maintained and the representation in it improved.

Consociational democracies and multicultural societies are particularly delicate in such areas as education and culture, where their reproduction and development is promoted. In that respect, the right to mother-tongue education, depending on countries' traditions, should be readily exercised. Some countries are labelled "multicultural", whereas such right is facultatively exercised (for example, primary- and secondary-school curricula in Australia foresee teaching the mother tongue of non-majority cultures 2 to 4 classes a week). Primary education in some countries is conducted either partially or in its entirety in the mother tongue of the non-majority cultural groups, but there are also instances where parts of the secondary and higher education is conducted likewise (for example, Swedes in Finland, Hungarians in Romania, Albanians in Macedonia, Serbs in Kosovo, etc.). The degree ofimplementing mother-tongue education mainly hinges on the political tradition, and hence international standards (Council of Europe's European Charter for Regional or Minority Languages and the Framework Convention for the Protection of National Minorities) determine but a minimal benchmark: provision of education in the mother tongue of the non-majority cultural groups, without establishing level and scope.

The second aspect of non-majority culture's reproduction represents media and cultural institutions (theatres, museums, science and art institutes, folklore institutions, archives, etc.). It is of utmost importance that media provide two types of opportunities: 1) ensuring access of non-majority ethnonational communities, or cultural groups, to information and cultural programmes in public media services, for which citizens pay taxes; and 2) in regard to private media, providing freedom of access and rules that would enable minority cultures to establish their own media.

One particular issue that may arise in this segment of cultural diversity and development is the useofthe mother tongue by non-majority cultures, as an idiosyncrasy of their identity and diversity (Martin Heidegger: "Language is the house of being"; BlažeKoneski: "Language is our homeland"; 
EqremÇabej: "Language is the clearest mirror of the people and their culture"; Holger Petersen: "Language is the sole means of moral enlightenment and progress of the people").

The issue can be addressed on a national level, and regulated either through the constitution and by a special law (Republic of Macedonia), or by law only in given areas-local government and registration of new companies - as in Germany, or through separate treatment of the each issue by thelaw on the specific area. The latter implies that such solutions ought to be presented within the pre-established constitutional framework. Anyhow, experience from consociational democracies or the elements of consociation in political systems suggests that,for its sensitivity, this issue persistently finds its wayhigh on the political agenda.

\section{Openness of Society and the Role of "Soft Arbitrage" in Multicultural Societies}

The mistrust that groups tend to introduce into the political debate is among the basic experiences of interethnic relations in politics.Mistrust can be rooted in rationality or irrationality. It can present a genuine attempt to deceive and manipulate, in order to access resources or in the fight for power. But, it can also have completely irrational roots associated with one's sense of endangerment, fear, discrimination and bad experience ensuing from the mutual relations of cultural groups. The level of prejudices may be high, along with the absence of social integration and mutual mingling on different bases. Hence, these societies are labelled "separated", "segmented" or "mosaic". Such level of mistrust in political dialogue is manifested with difficulties in realisation and functionality, stagnation and regression. At the same time, this generates heated atmosphere in these societies. Therefore, it is crucially important to establish the means and the type of methodology to perform talks and negotiations, at least concerning the most important issues on the political agenda. Namely, the experience of these countries suggests that the political debates should be open, even though they pertain to the internal regime. [2] There should be some form of "soft arbitrage", i.e.,a mediator played bythe international organisations or countries the groups trust. In cases when discussions reach an impasse or become "impossible", informal expert consultation might take place with professionals offering their expert opinion and guarantees on whether the solutions proposed are good or bad (including suggestions to improve them). In that way, minority groups sceptical about the willingness of the government or the majority group will have further assurance and might reach a position where they would accept a mutual solution. This methodology of playing a third party, or "soft arbitrage", is notably important in the initial establishment of consociational systems, especially during the first years, when conflict potential and mistrust between different cultural groups are acute and significant. Experience of some consociations, on the other hand, suggests that such methodology is readily applicable further on in the development of these democracies.Moreover, it becomes integral to the political culture of these consociations. Examples of "soft arbitrage" in pursuance of solutions that are mutually acceptable to different groups in such multi-ethnic societies are as follows: GerdArens and the Ohrid Framework Agreement in the Republic of Macedonia; Ahtisaari in Kosovo; Bill Clinton and The Good Friday Agreement in Northern Ireland; Dayton Agreement in Bosnia and Herzegovina; etc.

Another aspect of countries' openness similarly aids rationality and mitigation of cultural "hot" subjects in the political system of consociational democracies, namely, integration in international organisations and security arrangements. This element of international networking stabilises consociational democracies to a comparatively greater degree than countries of homogeneous nature. Thus, manifoldness is introduced, with multiple layers addressing the internal issues of these 
countries. This condition of international networking represents the third condition for the functioning of (consociational) democracy in multicultural societies.

\section{Responsibility of Political Elites, Political Culture of Inclusiveness and the Role of the Civil Sector}

Multicultural societies and their consociational democracy can function successfully only if the political elites of both cultural segments and ethnic political parties - the key state officials - exhibit high degree of responsibility and understanding for the complex circumstances of consociational democracy. In fact, one may observe a responsibility paradox of political elites. Political responsibility in these societies is by far needed the most, and yet, it is but sporadic. Political leaders find it easier to gain power through manipulation of their cultures and ethnic clans, whereas it all boils down to the grotesque manifestation of ethno-nationalism, instead of attaining effective consociational democracy. This condition is indicative of the person's role, personal responsibility and subjective factor in politics.

The responsibility of political elites in consociational democracies is mainly illustrated through the restraint and caution towards the dialogue conducted with other groups' political elites, the restraint to impose solutions (from one's cultural prism onto others) and patience, as well as the readiness to lead long negotiations and dialogues with other political elites in favour of finding a slow-paced mutual consensus. Also important is the persistence and integrity in the struggle for defence and implementation of these solutions against ethno-nationalist politicians.

And finally, political responsibility also entails the creation of a foreign policy agenda taking into account the openness and speedy integration of international organisations, as a condition to their stabilisation.

\section{The Role of the Civil Sector and Political Culture in Consociational Democracies}

The role of the civil sector - political culture in consociational democracies, is controversial for many things. This controversy ensues from the way in which culture segments live and reproduce their cultural clichés and from the attitude held towards other cultures. This set of qualities for the political leadership is sometimes very difficult to find in a single person or in a group of key leaders. Accordingly, the issue of leadership quality in consociational democracies, as we shall note, evolves into a separate scientific sub-discipline of the so called transitology or transition towards democracy. They often tend to be full of stereotypes, prejudices, distancing and history of tension with other cultures. This is openly seen and felt in the civil sector, especially in the presence of intensive social network, the Internet, free media, etc. One particular tendency is very emblematic of this type of societies. Namely, non-governmental organisations and networks organising the civil sector generally move along cultural delineations, instead of crossing them, as one may expect. This is the first experience in consociational democraciesand their civil sector. The second one is that the civil sector may represent an arena of intensive confrontation and hate speech, which only proves that the sole project of democracy in multicultural societies and different consociations is an elitist project (if one may say so), that is, democracy in these societies depends on the responsibility of political elites and their confidence in such a project. They - the elites-introduce self-control and restraint to their cultural segments in regard to the aggressive attitude towards other cultures. Also, the tolerant behaviour in a civil sector of such division is mainly owing to its international 
networking and the financial impact of important international organisations and democratic countries financing the projects.

It is important that the civil sector remains open to the civil influences related to the standards for human rights, tolerant communication and pressure against hate speech. This makes groups' cultural self-perceptions prone to evolution.

\section{Concluding Notes}

In this paper, attention was drawn to the identification of the necessary conditions for all consociation models. As regards these conditions, we have entered a territory previously not covered in its entirety by the relevant literature, thereby trying to provide a creative elaboration and discussion on such conditions for effective consociation. We identified them as normative-level conditions. In that context, inclusive constitutional provisions recognising and accepting collective cultural groups bear distinct importance. They also encompass different modes of protecting their culture, here including a form of the right to a veto. Furthermore, we also delved into the conditions related to responsibility and establishment of the political elites of culture identity groups in a consociational democracy, with due consideration of changes to and role of the civil sector. With reference to the role of the civil sector, where, in fact, a society's political culture is developed and effectuated, we have arrived at a conclusion [4,5] that there may arise several situations in which the society has elitistically agreed-upon consociational institutions, and still lack consociational culture; it shows a consensus of political culture which fails to be reflected in the consociational institutions and different intermediate situations. But, what is important, political culture affects political institutions and seeks support from them. Consociational democracy (some authors call consensual) may become inert, andthus incapable of integration and advancement, unless it gains support from the consociational political culture. Consociation-oriented culture often provides the basis to create consociational democracy institutions and their interconnectedness. If consociational (consensual) culture brings about the establishment of consociational institutions, such institutions have the potential to transform an initially antagonistic culture into one that is less antagonistic and more consensual. Finally, we also identified conditions pertaining to the openness and international standing (integration) of countries developing consociational democracy. In some instances they are not seen as a distinct model of consociational democracy, but instead, they merely present consociational traces in a classic model of majoritarian democracy (a trend some authors label democratisation ofdemocracy or re-democratisation).

One irrefragable conclusion about the minimal effectiveness of democracy with significant consociational elements is that there must be a constitutional institution and procedure ensuring justice to different groups of a society. In short, consociation and democracy in consociational societies, according to the author, show perspective and represent ground for potential study; hence, this paper is but a minor and modest contribution in that sense.

\section{References}

11. Фрчкоски, Љ.Д.:Преговарањевоконфликтинаидентитети.Темплум, Скопје(2010)

12. Lijphart, A.: Modelidemokratije. CID, Podgorica (2003)

13. Kymlicka, W.: Multicultural Odysseys: Navigating the New International Politics of Diversity.

Oxford University Press, Oxford (2007) 
14. Lijphart, A.: Democracies: Patterns of Majoritarian and Consensus Government in Twenty-one Countries. Yale University Press, New Haven and London (1984)

15. Lijphart, A.: Dimensions of Democracies.European Journal of Political Research (1997) 31: 193 